\title{
The influence of climate and soils on the distribution of four African grasses
}

JERRY R. COX, M.H. MARTIN-R, F.A. IBARRA-F, J.H. FOURIE, N.F.G. RETHMAN, AND D.G. WILCOX

\section{Abstract}

Around 1900 temperate and semidesert grassland productivity declined, soll erosion increased, and drought destabilined the livestock industry in the northern and southern hemispheres. As government leaders throughout the world began to recognine the importance of grassland productivity and soil conservation, a massive experiment began to evolve. Government and private individuals collected seed from every continent, and planted seed at experimental stations and ranches in their respective countries. Hundreds of individuals who conducted thousands of seeding trials observed that buffelegrass (Cenchrus cillaris L.), weeping lovegrass [Eragrostis curvula (Schrad.) Nees], kleingrass (Panicum coloratum L.), and Lehmann lovegrass (Eragrostis lehmanniana Nees) plants from seed collected in Africa were easier to establish and persisted longer than other graseses. Between 1930 and 1986 scientists in many countries evaluated the establishment and persistence of these grasses, but no attempt was made to synthesize the data base and determine the effects of climate and soil on plant estabIshment and persistence. Our objective was to: (1) determine the climatic and edaphic characteristics of areas where the seed of each grass was collected in Africa, and where each grass has been successfully established in both hemispheres, and (2) identify characteristies which infuence long-term persistence. Where buffelgrass predominates and spreads, summer rainfall varies from 150 to $550 \mathrm{~mm}$, winter rainfall is less than $400 \mathrm{~mm}$, mean miminum winter temperatures rarely fall below $5^{\circ} \mathrm{C}$, and soil texture is loamy. Weeping lovegrass can be established and plants persist when spring, summer, and fall rainfall varies from 490 to $1,000 \mathrm{~mm}$ on deep sandy soil and mean minimum winter temperatures rarely fall below $-5^{\circ} \mathrm{C}$. The invasion of adjacent nonplanted sites occurs only in Africa where growing season rainfall infrequently cycles between 750 and $1,000 \mathrm{~mm}$ and soils remain wet in mid-summer. Kleingrass can be established where mean maximum daily summer temperatures are above $30^{\circ} \mathrm{C}$, mean minimum dally winter temperatures rarely fall below $0^{\circ} \mathrm{C}$, summer growing season rainfall varies from 400 to $990 \mathrm{~mm}$, and solls are clayey or silty. Kleingrass, like weeping lovegrass, spreads to nonplanted sites only in Africa where a mid-summer drought does not occur. Lehmann lovegrass predominates and spreads only in southern Africa, southeastern Arizona, and northern Mexico when summer rainfall in 30 to 40 days exceeds $150 \mathrm{~mm}$, and soil textures are sandy or sandy loam.

Key Words: buffelgress, kleingrass, Lehmann lovegrass, weeping lovegrass, rangeland seeding, Northern and Southern hemispheres

\footnotetext{
Jerry Cox is range scientist, USDA, Agricultural Research Service, Aridland Watershed Management Research Unit, 2000 E. Allen Road, Tucson, Ariz. 85719 Martha-Martin- $R$ and Fernando Ibarra-F are head of the Department of Range Management and technical director, respectively, CIPES, Periferico OTS S/N, Conjunto UGRS, Postal 1754, Hermosillo, Sonora, Mexico; Jan Fourie is extension manager, Sentraalwes Agricultural Center, Bloemfontein, South Africa; Norman Rethman is professor, Department of Plant Production, Univ. of Pretoria, Pretoria,

South Africa; and David Wilcox is principal advisor, Department of Agriculture (retired), South Perth, Western Australia.

The authors wish to acknowledge the support of A.E. Bernardson, Univ. Nacional de La Pampa, Anguil, Argentina; O.A. Fernandez, Univ. Nacional del Sur, Bahia Blanca, Argentina; P. Zacharias, Univ. Natal, Pietermaritzburg, South Africa; R. Heizer and R.H. Johnson, USDA-Soil Conserv. Serv.; E.C. Bashaw, C.L. DeWald, M.C. Shoop, P.W. Voigt, and G.A. White, USDA-Agr. Res. Serv.; C.M. Taliaferro, Oklahoma State Univ.; C.W. Hanselka, Texas Agr. Ext. Serv.; and E.C. Holt (retired) and M.A. Hussey, Texas A\&M Univ. in accomplishing the objectives of this research. Manuscript accepted 1 October 1987.
}

Commercial and religious rivalries among the Dutch, English, Portuguese, and Spanish between 1450 and 1550 resulted in the establishment of shipping lanes and exploration of continental land boundaries. Coastal exploration was followed by colonization, and by 1900 European settlers and their livestock had occupied the seemingly endless temperate and semiarid grasslands of Africa, Australia, North America, and South America. As European man and domestic livestock numbers increased, there was a corresponding increase in weed and woody shrub densities, and grassland productivity declined (Sellers and Hill 1974, Cooke and Reeves 1976).

Between 1880 and 1930, frequent droughts occurred in Africa, Australia, and North America, and livestock numbers declined (Brooks 1929, Bogdan 1961, Cox et al. 1983a). In an attempt to stabilize livestock populations, botanists, ranchers, and military personnel from Australia, England, South Africa, and the United States travelled throughout the world searching for a "miracle grass" that could produce an abundance of good quality forage with limited precipitation. Attempts were also made to develop high-producing varieties through plant breeding that would surpass native species (Thornber 1905). Their approach was to: (1) collect seed from plants growing in harsh environments, (2) plant seed at experimental stations or ranches in their respective countries, (3) increase seed from species that appeared to be drought tolerant, and (4) plant seed under extreme climatic and edaphic conditions (Griffith 1901). From thousands of seeding trials conducted throughout the world, 4 warm-season African grasses were recognized for their ease of establishment, persistence, and forage production. The grasses were buffelgrass (Cenchrus ciliaris L.), weeping lovegrass [Eragrostis curvula (Schrad.) Nees], kleingrass (Panicum coloratum L.), and Lehmann lovegrass (Eragrostis lehmanniana Nees). The purpose of this paper is: (1) to determine where the original seed sources were collected, and by whom; (2) to determine where the $\mathbf{4}$ grasses have been successfully established from sown seed, where mature plants have persisted for more than 20 years, and where seed from mature plants has colonized new areas; (3) to discuss relationships between climate, soils, and pests which may influence the long-term persistence of the 4 grasses; and (4) to evaluate the results as they may apply to future seedings throughout the northern and southern hemispheres.

\section{Materials and Methods}

Historical records and journals were examined to determine (1) where seed were originally collected and (2) countries where each grass had been successfully established. Rangeland conservationists in each country provided estimations of the area sown to each grass as well as adjacent colonized areas.

Climatic and edaphic data were collected at or from nearby areas where seed were originally collected and where mature plants established from seed persisted for 20 or more years. Climatic reporting stations were selected based upon (1) topographic similarities between reporting stations and the area where seed were collected or established, and (2) having 10 or more years of continuous records which corresponded with actual planting or invasion years.

Climatic data are summarized in the following mean monthly categories: (1) maximum temperatures, (2) minimum tempera- 


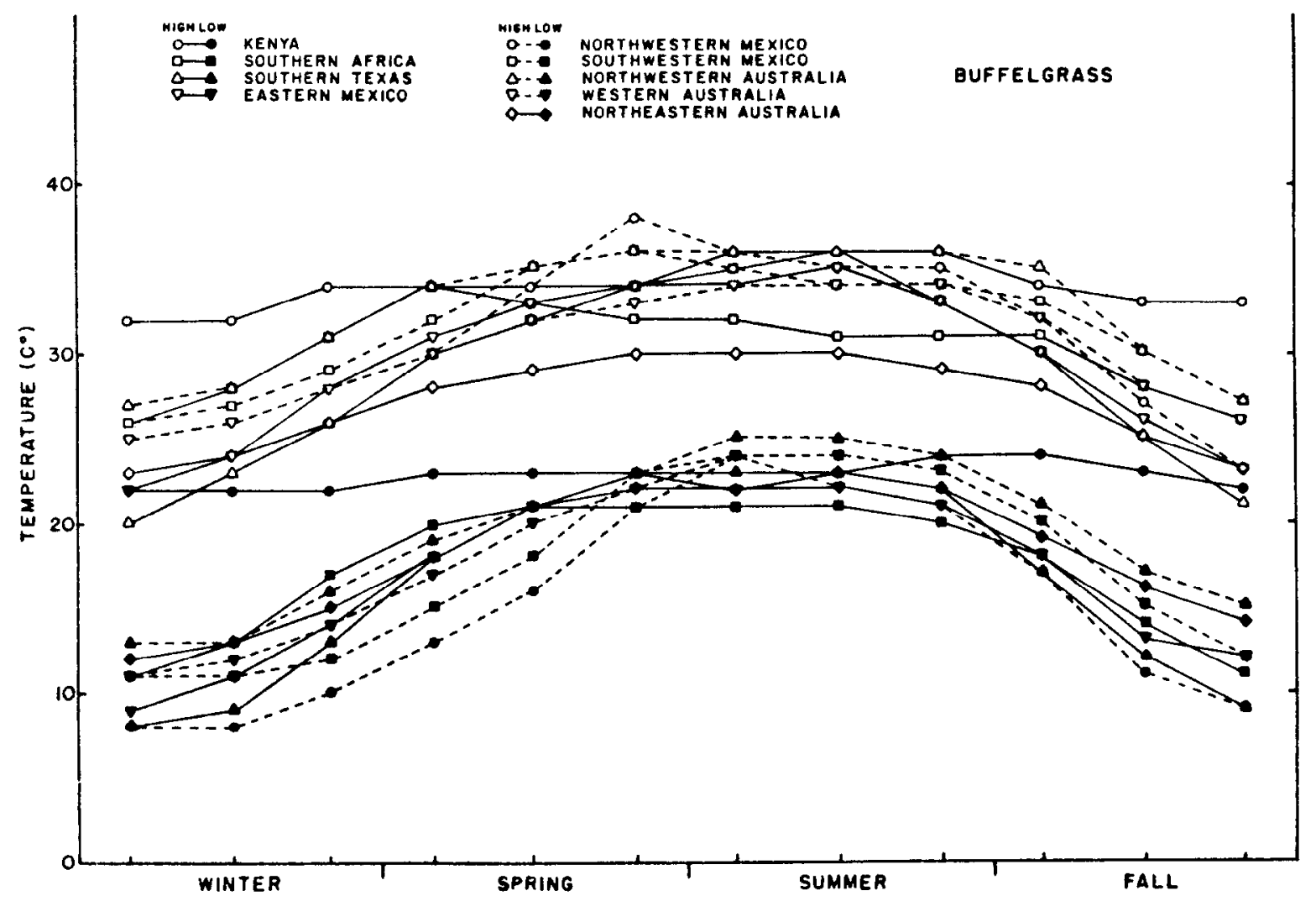

Fig. 1. Mean monthly maximum and minimum temperatures during winter, spring, summer, and fall where buffelgrass has been successfully established in the northern and southern hemispheres.

tures, and (3) precipitation. Data from stations in the northern and southern hemispheres are adjusted by month so that winter, spring, summer, and fall seasons correspond.

\section{Results}

Initial plant establishment from seed was documented in 31 countries for buffelgrass, 15 for weeping lovegrass, 9 for kleingrass, and 5 for Lehmann lovegrass. Long-term persistence and colonization, however, occurred only in 6 countries for buffelgrass, 3 for weeping lovegrass, 2 for kleingrass and 1 for Lehmann lovegrass.

\section{Buffelgrass}

C.J.J. van Rensburg, Department of Agriculture, South Africa, collected buffelgrass seed at many semiarid northeast African locations between 1940 and 1945 . Seed were sown at Rietvlei Plant Introduction Station near Pretoria and evaluated for establishment, persistence, and forage production. Plants from seed collected in the Turkana Desert of northcentral Kenya and southern Ethiopia in 1940 survived a drought in 1942, and a seed production program was initiated in 1945.

Seed from the Turkana Desert collection were shipped to the United States in 1946 (Holt 1985). Plants were successfully established and persisted in southern Texas, and the U.S. Department of Agriculture, Soil Conservation Service (USDA-SCS) informally released T-4464 buffelgrass in 1949. Between 1949 and 1985, Texas seed producers sold 7 million $\mathrm{kg}$ of T-4464 seed, and ranchers in southern Texas established the grass on over 4 million ha. Seed were transported south into Mexico and successfully established on 6 million ha along the eastern coast, and on 300,000 ha along the western coast. $T-4464$ as well as seed from other buffelgrass collections made in Pakistan and southern Africa (Ivory et al. 1974) were shipped to Australia and successfully established on 7.5 million ha in the western and northern territories (Humphreys 1967).

Various buffelgrass accessions have been selected for production and cold tolerance (Das et al. 1978, Ivory and Whiteman 1978, Khan and Zarif 1982). Neither factor, however, can be repeatedly shown to differ among accessions when tests were conducted under the same or similar climatic and edaphic conditions.

Where buffelgrass occurs in northcentral Kenya and southern Ethiopia, elevations vary from 150 to $700 \mathrm{~m}$, and mean monthly minimum and maximum temperatures annually vary from 21 to $24^{\circ} \mathrm{C}$ and 31 to $36^{\circ} \mathrm{C}$ (Fig. 1), respectively. Rainfall is bimodally distributed in 2 summer growing seasons, and annually varies from 200 to $400 \mathrm{~mm}$. Buffelgrass is generally found growing in loam and sandy clay loam soils, and growth occurs whenever soil moisture is available (National Animal Husbandry Research Station Annual Report from Naivasha, Kenya 1979).

Where buffelgrass has been successfully established from seed, elevations vary from 6 to $830 \mathrm{~m}$; but mean minimum winter temperatures at these locations are 10 to $15^{\circ} \mathrm{C}$ colder than in the Turkana Desert (Fig. 1). Leaf growth begins when mean minimum temperatures rise above $10^{\circ} \mathrm{C}$. but active growth occurs only in summer when mean minimum temperatures are between 15 and $20^{\circ} \mathrm{C}$ and mean maximum temperatures are below $40^{\circ} \mathrm{C}$ in southern Africa (du Toit et al. 1973, Dye and Walker 1980), northeastern and northwestern Australia (Humphreys 1967, Sweeney and Hopkinson 1975, Harsh et al. 1981), eastern and western Mexico (Cota and Johnson 1975, Molina et al. 1976), and the southcentral United States (Hanselka 1985). Annual rainfall varies from $200 \mathrm{~mm}$ in the Turkana Desert and northwestern Mexico to $1,250 \mathrm{~mm}$ in northeastern Australia, and may be distributed in 


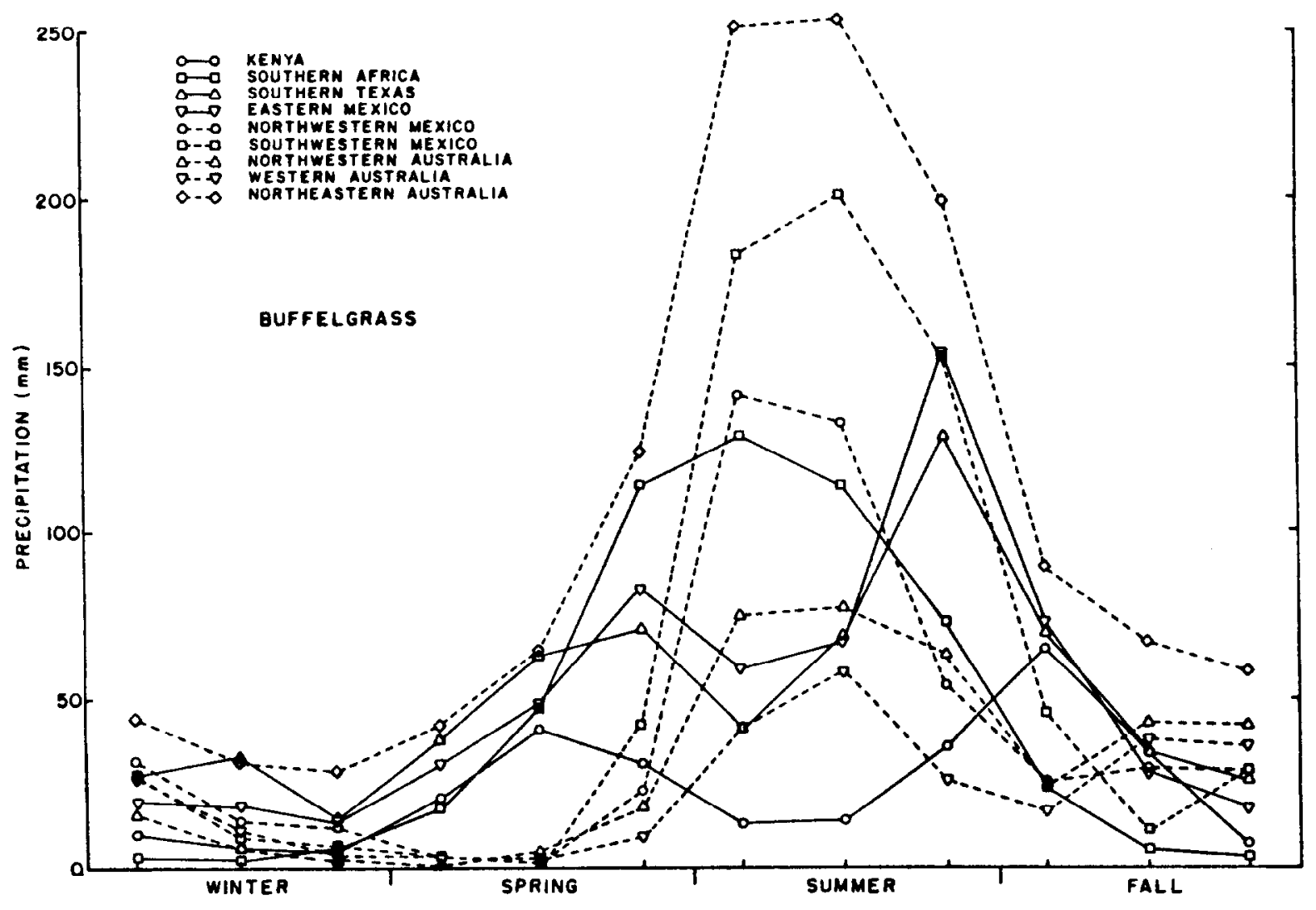

Fig. 2. Mean monthly precipitation during winter, spring, summer, and fall where buffelgrass has been successfully established in the northern and southern hemispheres.

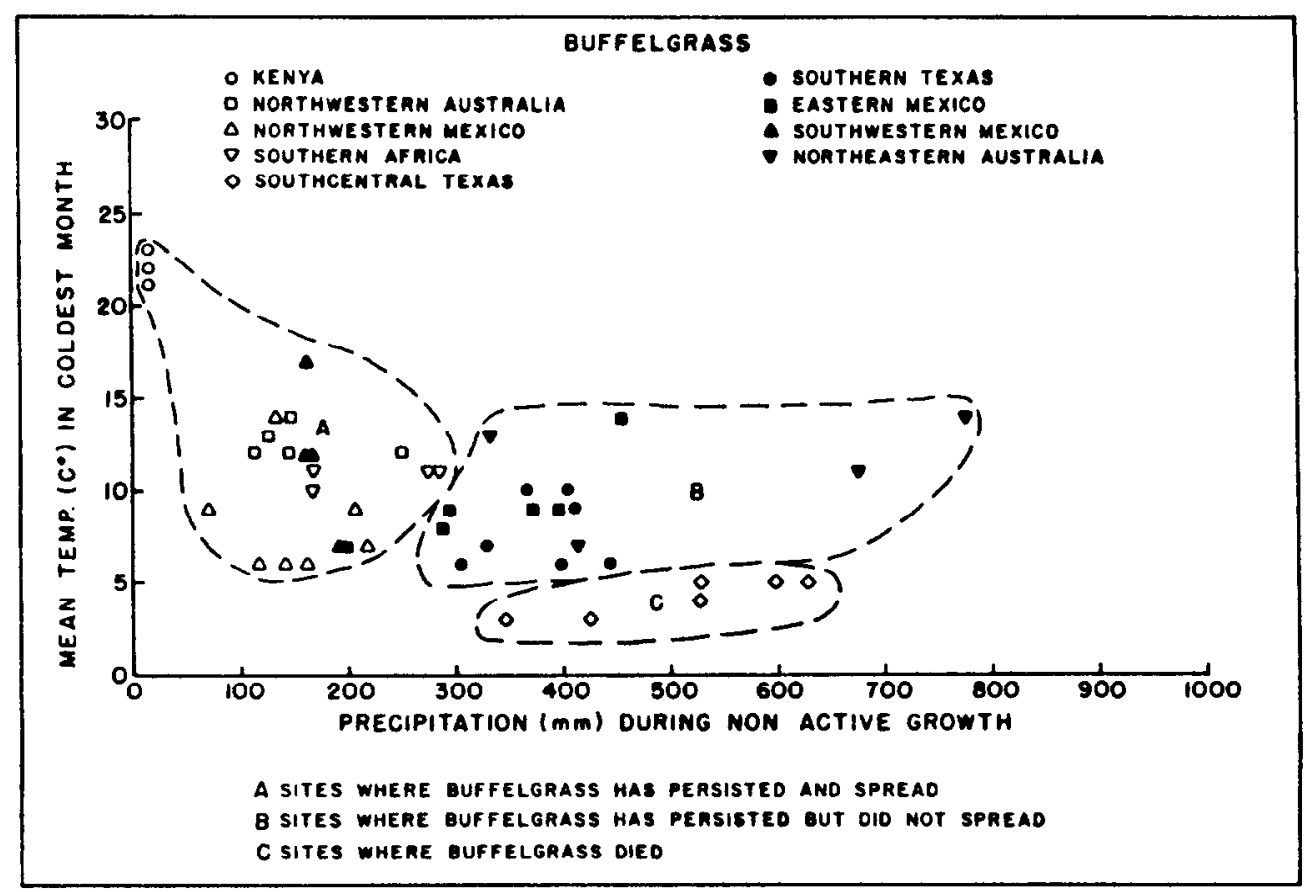

Fig. 3. The effect of mean winter temperature and winter precipitation on the long-term persistence of buffelgrass in the northern and southern hemispheres. 
either a summer peak, bimodally in summer, bimodally in summer and fall or bimodally in summer and winter.

Buffelgrass seed, from plants established on planted sites, actively colonize adjacent nonplanted sites in Kenya, southern Africa, northwestern Australia, and northwestern Mexico. At all locations, summer rainfall during active plant growth varies from 170 to $400 \mathrm{~mm}$ while rainfall during dormancy varies from 10 to $285 \mathrm{~mm}$ (Fig. 2); dry periods totalling 150 to 210 days occur in either winter or in fall and spring; and mean minimum temperatures in the coldest month range between 0 and $23^{\circ} \mathrm{C}$. Under such conditions, buffelgrass seed in soil may remain viable for 3 years (Winkworth 1963).

Established stands persist but do not actively colonize adjacent nonplanted sites in northeastern Australia, southwestern Mexico, eastern Mexico, and southern Texas. Summer rainfall exceeds 440 $\mathrm{mm}$ in northeastern Australia and southwestern Mexico, while rainfall during dormancy generally exceeds $300 \mathrm{~mm}$ in northeastern Australia, eastern Mexico and southern Texas (Fig. 2). Plant distribution under these environmental conditions is limited by allelopathy (Hussain and Ilahi 1982), competition with more productive forbs and grasses (Sweeney and Hopkinson 1975), insects which reduce plant vigor (Reis et al. 1984), and pathogens (Azmi and Singh 1985) which reduce seed germination during extended wet periods in either summer or winter.

In southcentral Texas, mean minimum temperatures in the coldest month are below $6^{\circ} \mathrm{C}$, rainfall during dormancy generally exceeds $400 \mathrm{~mm}$ (Fig. 3), and an extended dry period does not occur. Stands established under these conditions fail to persist because seed produced in summer is destroyed during wet winters (Amzi and Singh 1985) and established plants die during cold winters (Holt 1985).

\section{Weeping Lovegrass}

L.W. Kephart and R.L. Piemeisel, Bureau of Plant Industry, U.S. Department of Agriculture, collected weeping lovegrass seed in northcentral Tanzania in 1927 (Crider 1945). Seed were collected from plants growing in black, waxy, sun-cracked soil on an escarpment between Mbula and Ngorongoro Craters, where elevation varied from 1,300 to $1,800 \mathrm{~m}$.

Seed were shipped to Arizona in 1932 and numbered A-67
(Crider 1945). Weeping lovegrass was initially thought to be adapted in the semiarid southwestern United States, but mature plants were unable to survive spring and summer droughts (Bridges 1941, Judd and Judd 1976). Mature plants from seed planted in Oklahoma and northwestern Texas, however, did persist and between 1940 and 1980 A-67 weeping lovegrass was established on 800,000 ha.

In 1947 and 1953 seed from collections in Oklahoma were transported to Argentina and plants were established on 800,000 ha (Covas and Carinie 1985). Seed were also transported and established in southeastern Australia (Lloyd et al. 1983, Watt 1983), southern Africa (Kruger and Grunow 1983, Kategile 1985), Japan (Nada 1985), and Spain (Nieto 1985).

Three major weeping lovegrass types, selected for leafiness and cold tolerance, have been and are currently being compared to A-67. 'Morpa' (more palatable) was collected by R.K. Godfrey, Bureau of Plant Industry, U.S. Department of Agriculture, at Rietvlei Plant Introduction Station near Pretoria, South Africa in 1953. Seed were planted at Woodward, Oklahoma, in 1954, and seed from mature plants that survived in harsh winter in 1955-1956 were increased (Voigt 1971). 'Morpa' is taller, leaves are wider, and plants mature earlier than A-67 (Novosad et al. 1983). Beef cattle and sheep prefer 'Morpa'and gain weight faster than when grazing A-67 (Shoop et al. 1976).

'Ermelo', a leafy weeping lovegrass type was collected $200 \mathrm{~km}$ southeast of Pretoria at Nooitgedacht Research Station in 1944. Elevation is $1,750 \mathrm{~m}$ and nighttime temperatures are frequently below freezing in fall, winter, and spring. 'Ermelo' was introduced into the United States in 1948, and a second ecotype from an 'Ermelo' seeding in Zimbabwe was introduced in 1964.

Weeping lovegrass seeds collected from 54 sites in Basutoland (currently Lesotho) were increased by the Department of Agriculture and Technical Services in Pretoria and shipped to the United States in 1964. One selection, Renner, was more palatable and vigorous than the others. Renner has blue-green leaves and leaves are broader than A-67, 'Ermelo' and 'Morpa'. Renner was released in 1972 by the Texas Research Foundation (Read et al. 1980).

Differences among the 4 weeping lovegrass types, which do not include all African types, are related to leaf size, vigor, palatability

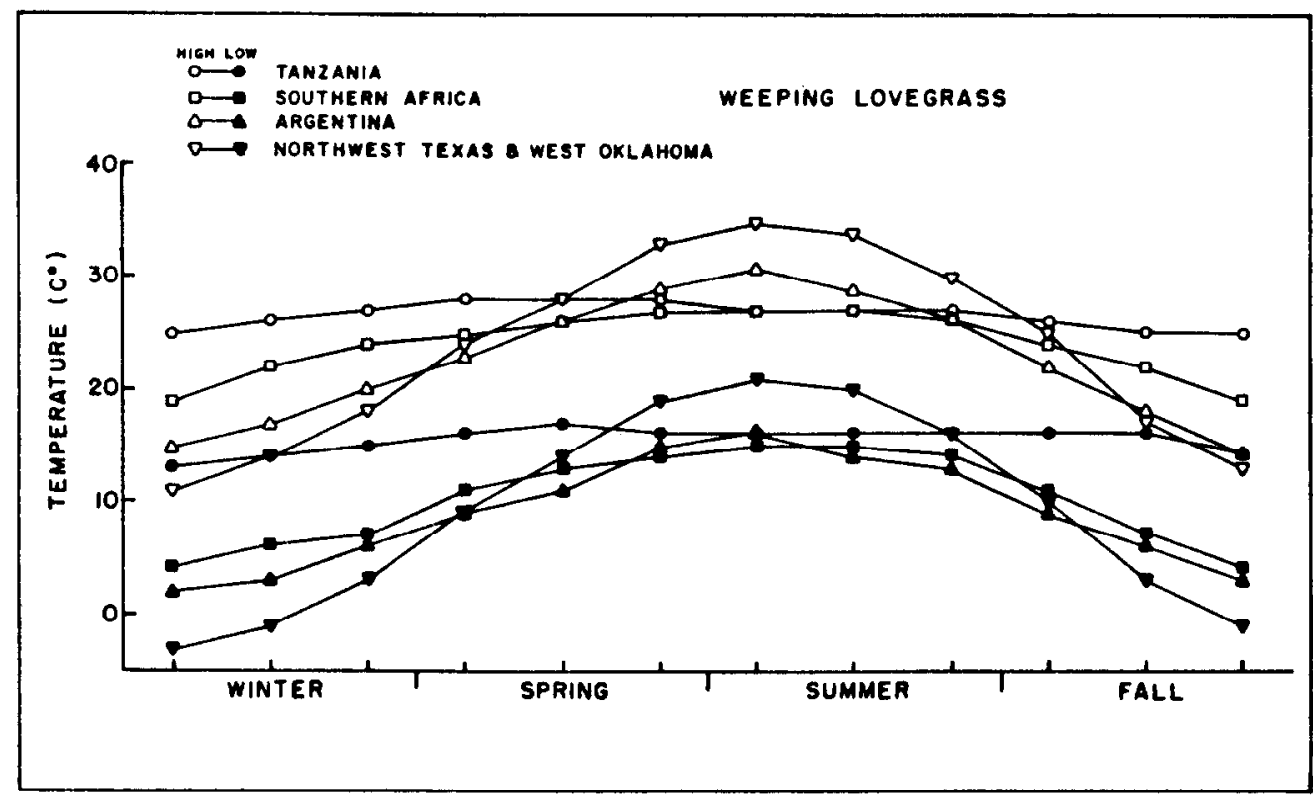

Fig. 4. Mean monthly maximum and minimum temperatures during winter, spring, summer and fall where weeping lovegrass has been successfully established in the northern and southern hemispheres. 


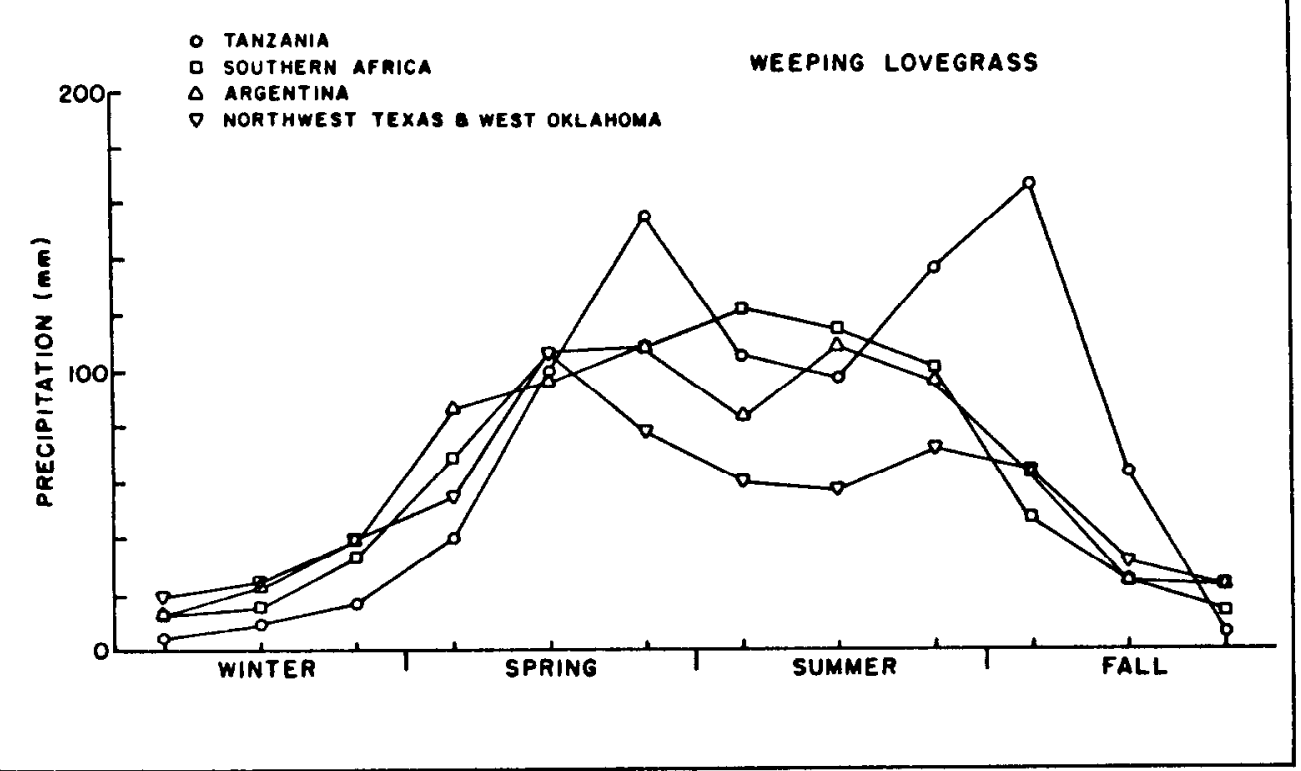

Fig. 5. Mean monthly precipitation during winter, spring, summer, and fall where weeping lovegrass has been successfully established in the northern and southern hemispheres.

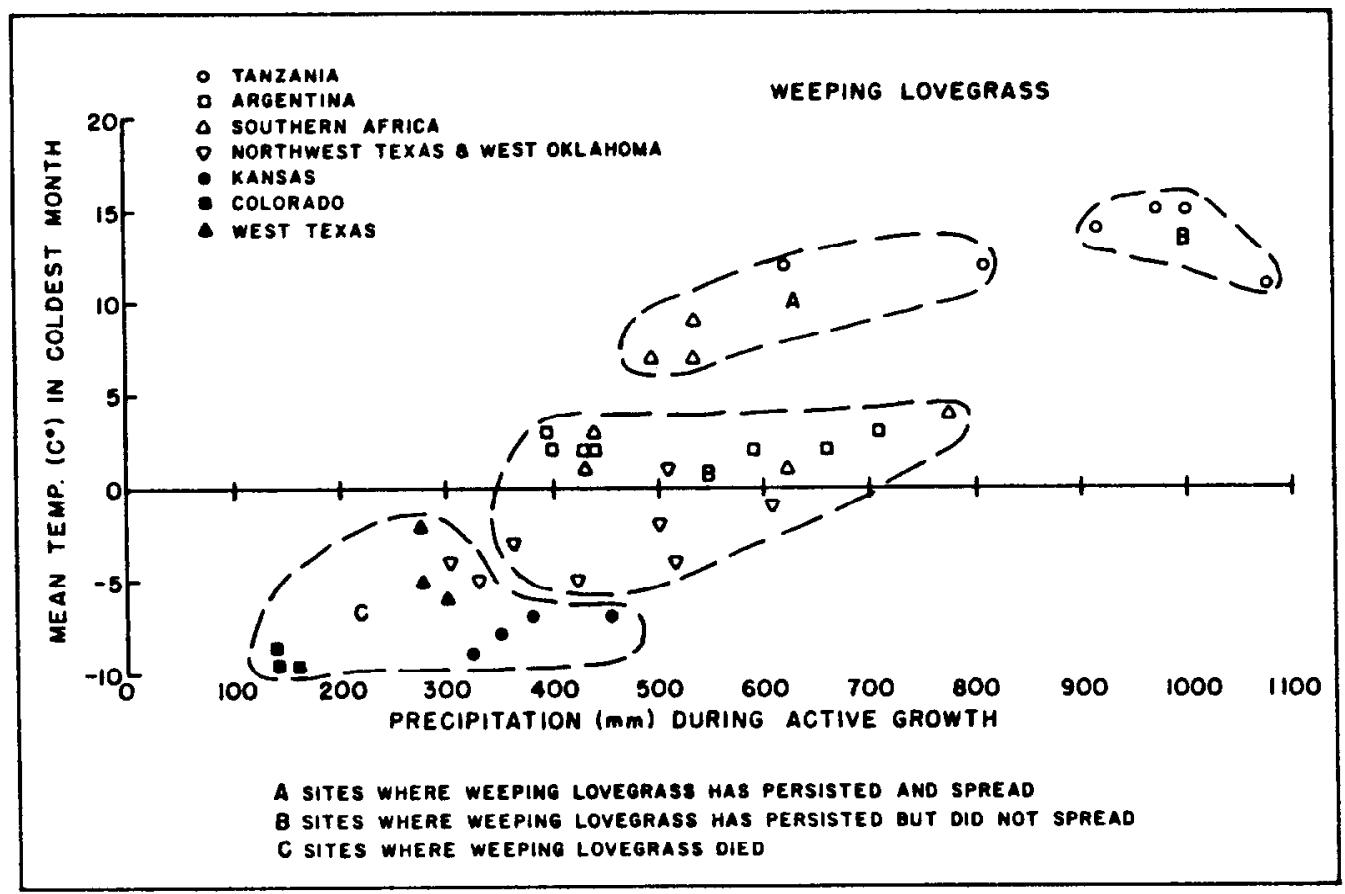

Fig. 6. The effect of mean winter temperature and summer precipitation on the long-term persistence of weeping lovegrass in the northern and southern hemispheres.

and possibly cold tolerance. The 4 types, however, represent most of the potential variability within the weeping lovegrass complex (Kruger and Grunow 1983). Thus, all types will be considered as 1 in our discussion.

In northcentral Tanzania where weeping lovegrass occurs, elevations vary from 1,190 to $1,530 \mathrm{~m}$. Mean monthly minimum and maximum temperatures range from 10 to $18^{\circ} \mathrm{C}$ and 25 to $30^{\circ} \mathrm{C}$, respectively (Fig. 4). Rainfall is bimodally distributed in summer and fall, and annually varies from 625 to $1,075 \mathrm{~mm}$. More than $80 \%$ of the annual rainfall ( 765 to $965 \mathrm{~mm}$ ) occurs when mean minimum daily temperatures are above $15^{\circ} \mathrm{C}$, and winter and spring are typically cool and dry. Weeping lovegrass generally grows in deep sand or loamy sand. Leaf growth occurs when early summer rains begin, productivity peaks in mid-summer just prior to or during a 
moderate dry period, and regrowth occurs in fall (Mukurasi 1984).

Weeping lovegrass has been successfully established from seed in southern Africa, southcentral Argentina, and southcentral United States, but the species does not actively colonize adjacent nonplanted sites. In South Africa, on the Natal Highlands and northern Transvaal Plains, weeping lovegrass has been established at 700 to 1,750 m elevations, while in Argentina plants are most often established at 80 to $310 \mathrm{~m}$ elevations. Winters in Tanzania, South Africa, and Argentina are cold and dry (Fig. 4), but mean minimum winter temperatures in Tanzania are 8 to $10^{\circ} \mathrm{C}$ warmer than in South Africa and Argentina.

Rainfall in South Africa peaks in mid-summer and annually varies from 500 to $1,200 \mathrm{~mm}$, while rainfall in Argentina peaks in early and late summer and annually varies from 640 to $955 \mathrm{~mm}$ (Fig. 5). Rainfall in the growing season ranges from 400 to $775 \mathrm{~mm}$, at both locations, and mean maximum summer temperatures rarely exceed $30^{\circ} \mathrm{C}$. Plant growth occurs when soil moisture is available and mean minimum temperatures rise above $10^{\circ} \mathrm{C}$, and productivity peaks in mid-summer when mean minimum and maximum temperatures vary between 15 and $30^{\circ} \mathrm{C}$ (Kruger and Grunow 1983, Rethman and de Witt 1984, Covas and Cairnie 1985).

In the United States, weeping lovegrass has been established from southern Colorado to southern Arizona and from Maryland to Georgia (Crider 1945, Denman et al. 1953). Plant persistence, however, is limited to 300 to $1,000 \mathrm{~m}$ elevations in western Oklahoma, and northwestern and northcentral Texas. Plant growth begins in late spring when mean minimum temperatures rise above $10^{\circ} \mathrm{C}$; productivity peaks when mean minimum and maximum temperatures range between 15 and $30^{\circ} \mathrm{C}$; growth declines in mid-summer when mean maximum temperatures exceed $30^{\circ} \mathrm{C}$ and soils dry (Shoop and McIlvain 1970).

In western Oklahoma and northwestern and northcentral Texas, mean minimum daily temperatures in the coldest month vary from -1 to $-5^{\circ} \mathrm{C}$ (Fig. 6) and minimum daily temperatures in winter are below $0^{\circ} \mathrm{C}$ for 60 to 90 days. Under such conditions established weeping lovegrass stands will persist if they are not fertilized and defoliated prior to freezing winter temperatures (Rommann and McMurphy 1974). To the north in southern Kansas and west in southeastern Colorado, mean minimum temperatures in the coldest month vary from -7 to $-10^{\circ} \mathrm{C}$ and daily minimum temperatures are below $0^{\circ} \mathrm{C}$ for 120 to 160 days. Weeping lovegrass can be established during summer in Kansas and during atypically wet summers in Colorado, but plants die in winter (Dwyer et al. 1974, Dalrymple 1976, Shoop et al. 1976, Read et al. 1980, Novosad et al. 1983). Stands can also be established during atypically wet summers and they persist for 10 or more years in southern Arizona, eastern New Mexico, and west Texas; but mature plants die when summer rainfall declines to $350 \mathrm{~mm}$ (Bridges 1941, Judd and Judd 1976).

Weeping lovegrass has been used throughout the world to revegetate mine spoils and steep slopes (Cresswell 1973, Farrington 1973, Wang et al. 1975, Voigt et al. 1982). Established stands persist where summer rainfall varies from 400 to $1,000 \mathrm{~mm}$, and mean minimum and maximum temperatures annually vary from 0 to $30^{\circ} \mathrm{C}$. Plant production, however, declines where summer rainfall exceeds 7? $\mathrm{mm}$ because of allelopathy (Dalrymple and Rogers 1983), competition with other forbs and grasses (Giraudo et al. 1984), fungal infections (van der Merwe et al. 1979), mites (Ehara 1985), and nematodes (Gnanapragasam 1981, van den Berg 1985).

\section{Kleingrass}

Dr. Mildred Wilman, Director of the McGregor Museum, Kimberley, South Africa, collected kleingrass seed between Kimberley in the Orange Free State and Potchefstroom in the Transvaal in 1949. Seed from the collections were planted throughout Texas between 1954 and 1968. Plants were successfully established in central Texas, and in 1968 the USDA-SCS and the Texas Agricultural Experiment Station jointly released Selection 75 (Holt 1969).

Between 1975 and 1985, commercial seed producers in Texas sold over 2 million $\mathrm{kg}$ of Selection 75 seed, and seed were planted on $\mathbf{2 . 8}$ million ha of degraded rangeland. Seed were transported and established on small acreages in eastern Australia (Rees 1972), Brazil (Alberto and Barreto 1983), Cuba (Oquendo et al. 1983), India (Mukherjee 1972), Japan (Inosaka et al. 1975), Venezuala (Gallardo and Leone 1983) and Zimbabwe (Mills 1977).

Kleingrass variety makarikariense, originally collected in Botswana, has a bluish color and wider leaves than Selection 75 (Holt et al. 1985). Makarikariense has been successfully established on small acreages in eastern Australia (Lloyd et al. 1983), Brazil (Alberto and Barreto 1983), and Japan (Inosaka et al. 1975).

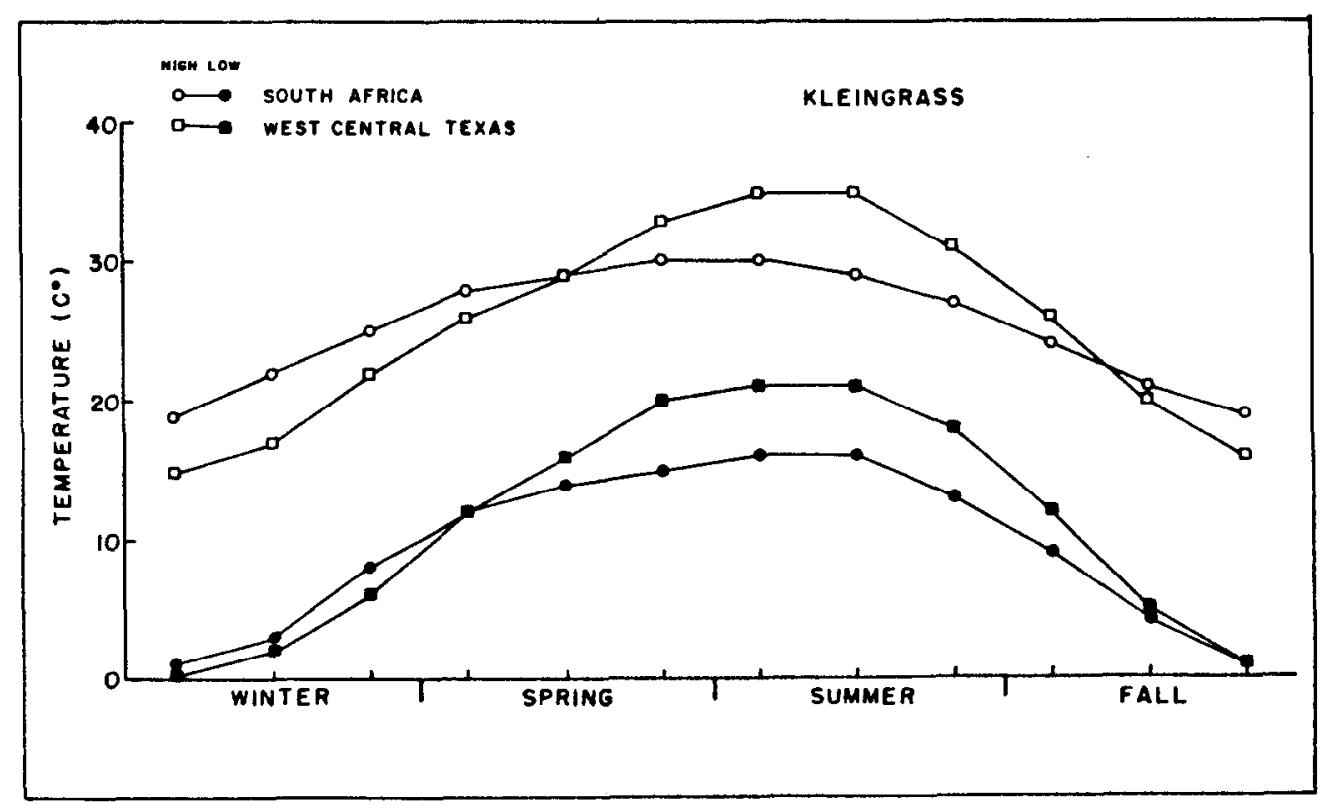

Fig. 7. Mean monthly maximum and minimum temperatures during winter, spring, summer, and fall where kleingrass has been successfully established in the northern and southem hemispheres. 


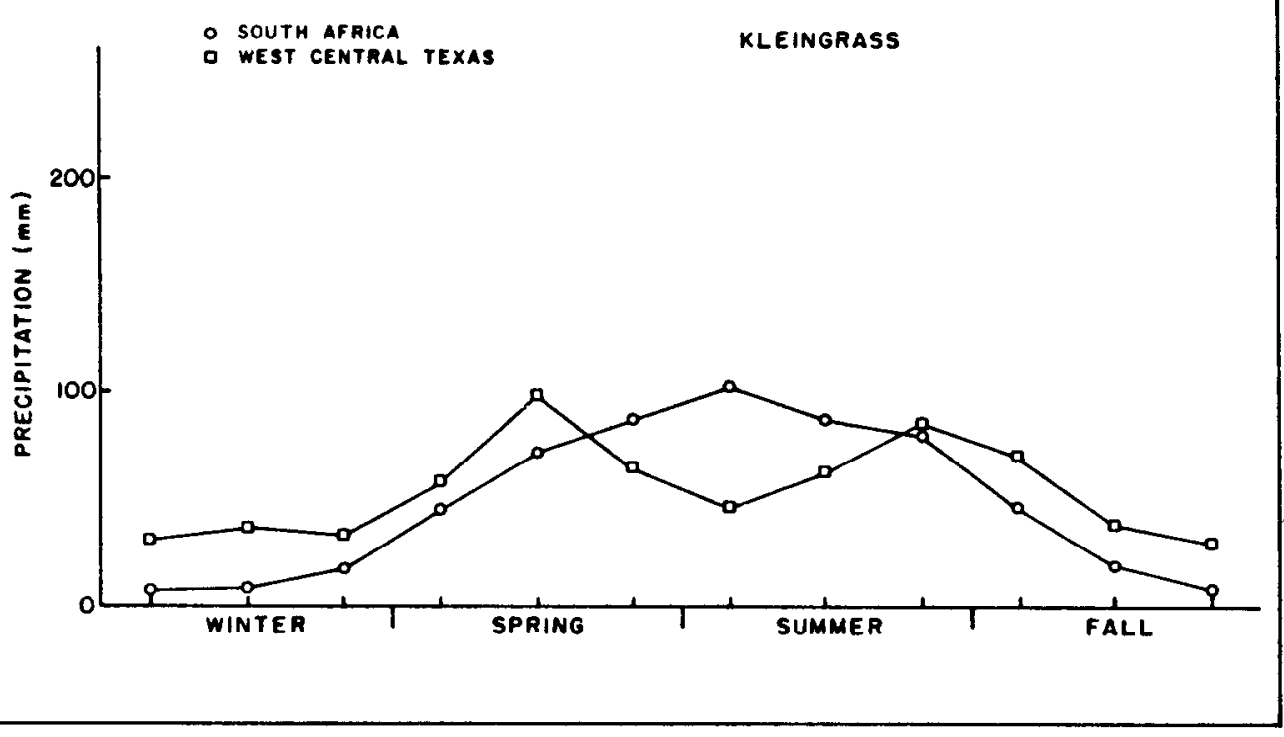

Fis. 8. Mean monthly precipitation during winter, spring, summer, and fall where kleingrass has been successfully established in the northern and southern hemispheres.

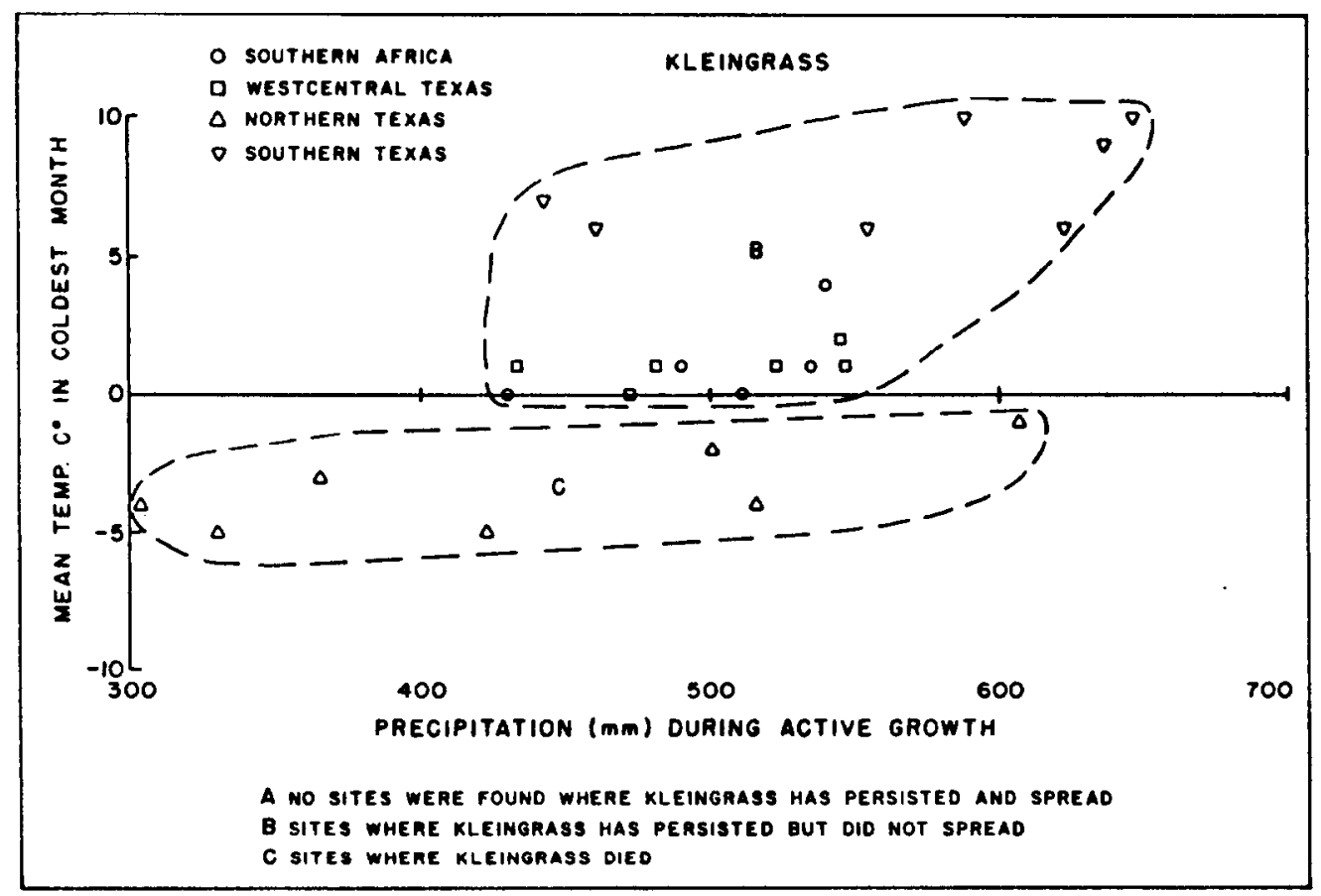

Fig. 9. The effect of mean winter temperature and summer precipitation on the long-term persistence of kleingrass in the northern and southern hemispheres.

Selection 75 is apparently more cold tolerant than makarikariense, but their establishment, productivity, and digestibility characteristics under moisture stress are similar (Kobayashi et al. 1978, MacKenzie et al. 1982, Bade et al. 1985). Thus, both selections are considered as one in our discussion.

Elevations in the western Transvaal of South Africa range from
1,000 to $1,450 \mathrm{~m}$, and mean monthly minimum and maximum temperatures annually vary from -2 to $17^{\circ} \mathrm{C}$ and 16 to $31^{\circ} \mathrm{C}$ (Fig. 7), respectively. Rainfall peaks in summer, and annually varies from $425 \mathrm{~mm}$ at Kimberley to $610 \mathrm{~mm}$ at Potchefstroom. Winters are dry, and mean minimum daily temperatures in the coldest month vary from -5 to $4^{\circ} \mathrm{C}$. In Zimbabwe, 200 to $300 \mathrm{~km}$ north, 
kleingrass grown under a similar climatic regime initiated growth in spring when temperatures approached $10^{\circ} \mathrm{C}$ and moisture in the soil was available (Rodel and Boultwood 1981). Plant productivity peaked when mean daily minimum and maximum temperatures ranged from 15 to $30^{\circ} \mathrm{C}$, and seedlings and mature plants were most often found where fine soil particles and water accumulated (Rodel 1972).

Kleingrass has been successfully established from seed in Australia (Rees 1972), Brazil (Alberto and Barreto 1983), Japan (Kobayashi et al. 1978), United States (Holt 1969), Venezuela (Gallardo and Leone 1983) and Zimbabwe (Rodel 1972), but the species does not actively colonize adjacent nonplanted sites. The species can be expected to survive extreme fall defoliation only in west central Texas (Holt et al. 1985) and southern Africa (Rodel and Boultwood 1981).

In west central Texas, elevations range from 440 to $540 \mathrm{~m}$, and mean minimum and maximum temperatures annually vary from 0 to $22^{\circ} \mathrm{C}$ and 12 to $36^{\circ} \mathrm{C}$ (Fig. 7), respectively. Winters are dry in some years while wet in others, and mean minimum daily temperatures in the coldest month vary from 0 to $2^{\circ} \mathrm{C}$. Rainfall is bimodally distributed, and peaks occur in late spring and early fall (Fig. 8). If soil moisture is available kleingrass grows from spring to fall when mean minimum daily temperatures are above $10^{\circ} \mathrm{C}$. Plant productivity peaks throughout summer when mean maximum temperatures range from 30 to $36^{\circ} \mathrm{C}$ (Stubbendieck et al. 1973, Pitman and Holt 1983, Bade et al. 1985, Bedunah and Sosebee 1985). Weeping lovegrass productivity, under similar temperature extremes, rapidly declines even when soil moisture is available (Farrington 1973, Mills 1977, Covas and Cairnie 1985).

Kleingrass persistence is limited by temperature to the north and by precipitation west of west-central Texas (Taliaferro et al. 1983), while production is limited by competition to the east and south (Holt et al. 1985). Established kleingrass stands in northern Texas and Oklahoma die (Holt 1969) where mean minimum daily temperatures in the coldest month vary from -1 to $-5^{\circ} \mathrm{C}$ (Fig. 9) and minimum daily temperatures in winter are below $0^{\circ} \mathrm{C}$ for 30 to 60 days; whereas in west Texas, stands die if total precipitation in the growing season (April to October) is less than $400 \mathrm{~mm}$ (Pratt et al. 1971). Kleingrass can be successfully established and will persist in high rainfall ( 700 to $990 \mathrm{~mm}$ ) areas of east and south Texas, but competition with other seeded grasses reduces kleingrass forage production (Hussey and Holt 1982). Production in high rainfall areas may also be limited by nematodes (Rodel et al. 1976).

Toxins accumulate in kleingrass foliage, and goats and sheep may die after consuming large quantities during fall in southern Africa (Rodel 1972) and summer and fall in central Texas (Dollahite et al. 1977, Muchiri et al. 1980). The distribution of kleingrass, as a potential pasture grass, may be limited because of its toxic characteristics.

\section{Lehmann Lovegrass}

Dr. Mildred Wilman, Director of the McGregor Museum, Kimberley, South Africa, sent Lehmann lovegrass seed collected in the Griqualand West Region of South Africa to F.J. Crider at Superior, Arizona, in 1932 (Crider 1945). In 1935, Crider organized a series of irrigated screening tests at Tucson, Arizona, and selected plants that matured quickly and produced seed in the first growing season. Seeds from established plants were numbered A-68.

Between 1937 and 1950, approximately $135 \mathrm{~kg}$ of Lehmann lovegrass seed, produced at Tucson, was planted in small plots from west Texas to Arizona. Many of the seedings were successful, and between 1951 and 1985, commercial seed growers produced more than $75,000 \mathrm{~kg}$ of Lehmann lovegrass seed. Approximately $70 \%$ of the seed was sown on rangelands in Arizona, New Mexico, and Texas. The majority of the remaining seed was transported into Mexico and planted in the northern frontier states of Chihuahua, Coahuila, and Sonora (Cota and Johnson 1975, Sanchez 1976, Cox et al. 1984). Between 1940 and 1980, ranchers and government agencies successfully established Lehmann lovegrass on more than 70,000 ha and the species spread by seed to an additional 70,000 ha in the southwestern United States and northern Mexico (Cox and Ruyle 1986).

Elevations in west-central South Africa where Lehmann lovegrass occurs naturally, range from 1,175 to $1,350 \mathrm{~m}$ and mean minimum and maximum temperatures annually vary from 0 to $19^{\circ}$ $\mathrm{C}$ and 18 to $34^{\circ} \mathrm{C}$ (Fig. 10), respectively. Annual rainfall peaks in late summer, and approximately $80 \%$ (225 to $395 \mathrm{~mm}$ ) is distributed in late spring, summer and early fall when mean minimum daily temperatures are above $15^{\circ} \mathrm{C}$. Rainfall amounts are low and storms are widely distributed in late spring and summer, and

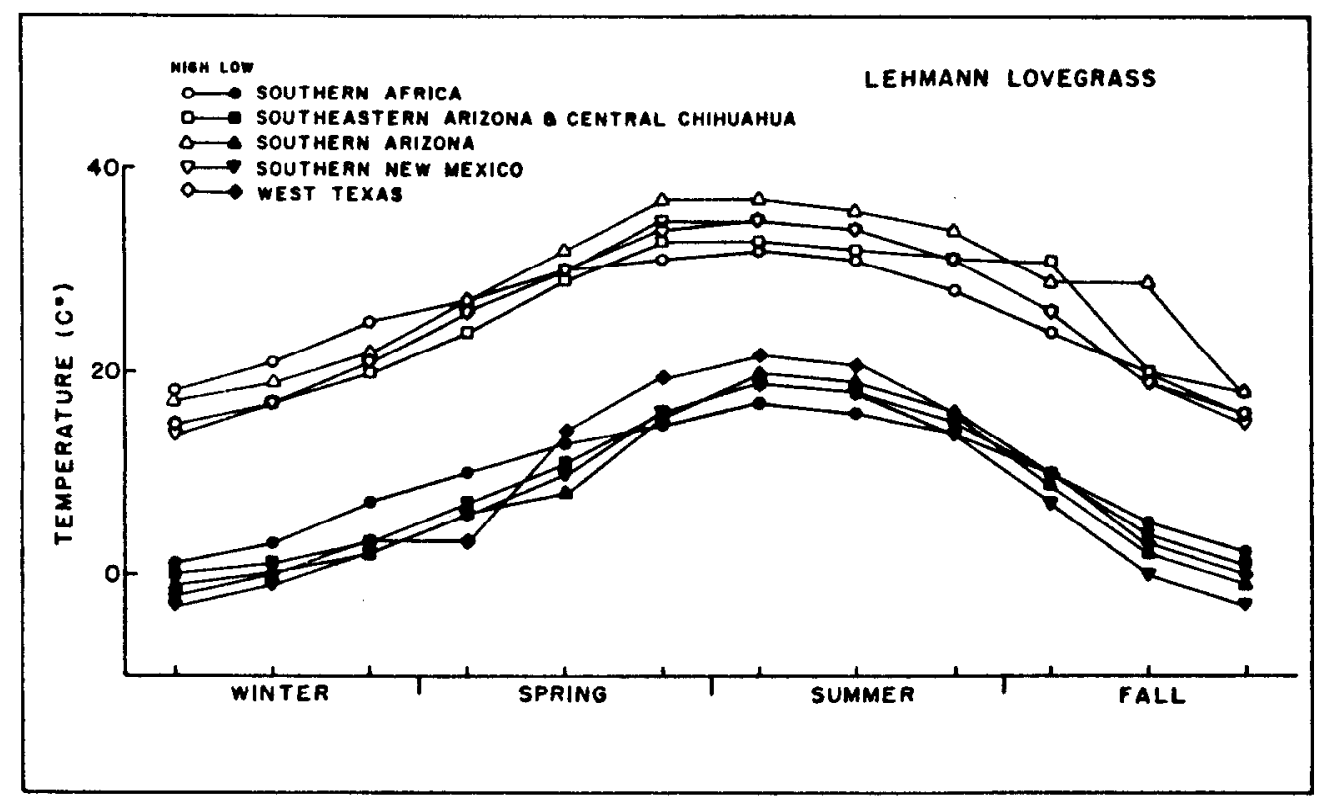

Fis. 10. Mean monthly maximum and minimum temperatures during winter, spring, summer and fall where Lehmann lovegrass has been successfully established in the northern and southern hemispheres. 


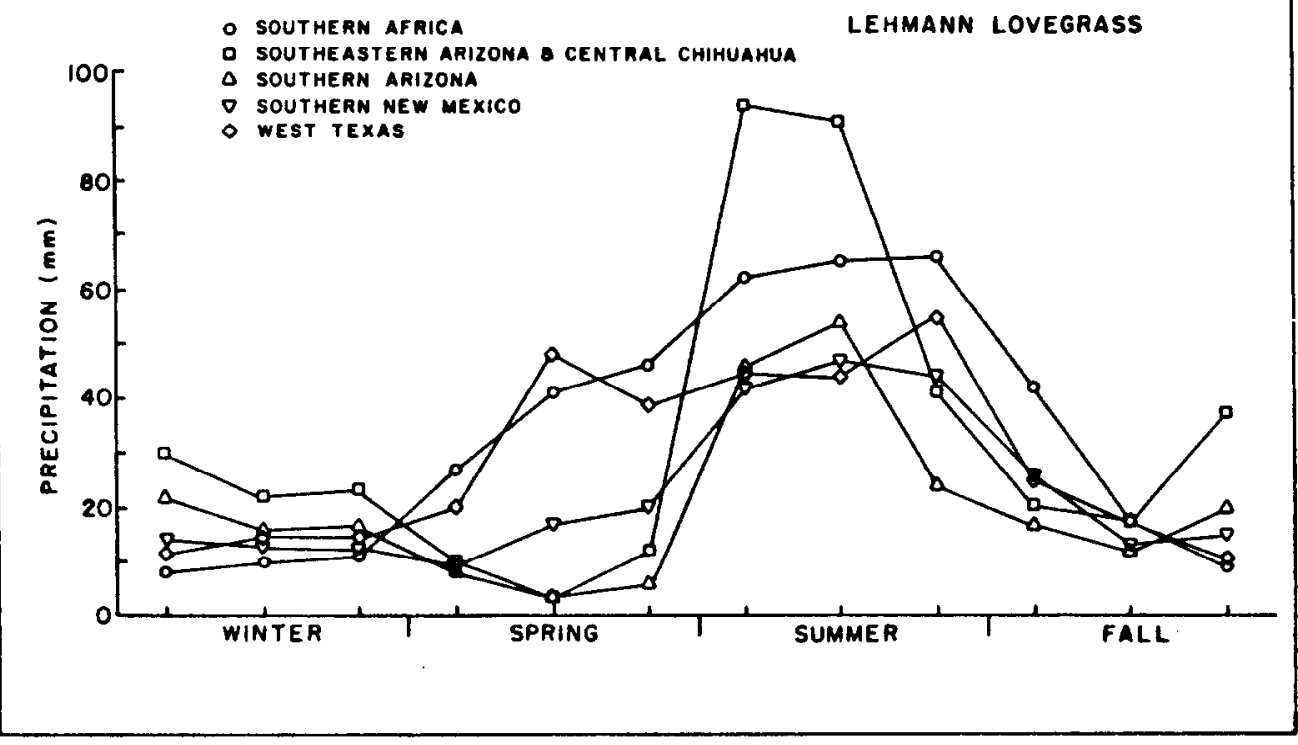

Fig. 11. Mean monthly precipitation during winter, spring, summer and fall where weeping lovegrass has been successfully established in the northern and southern hemispheres.

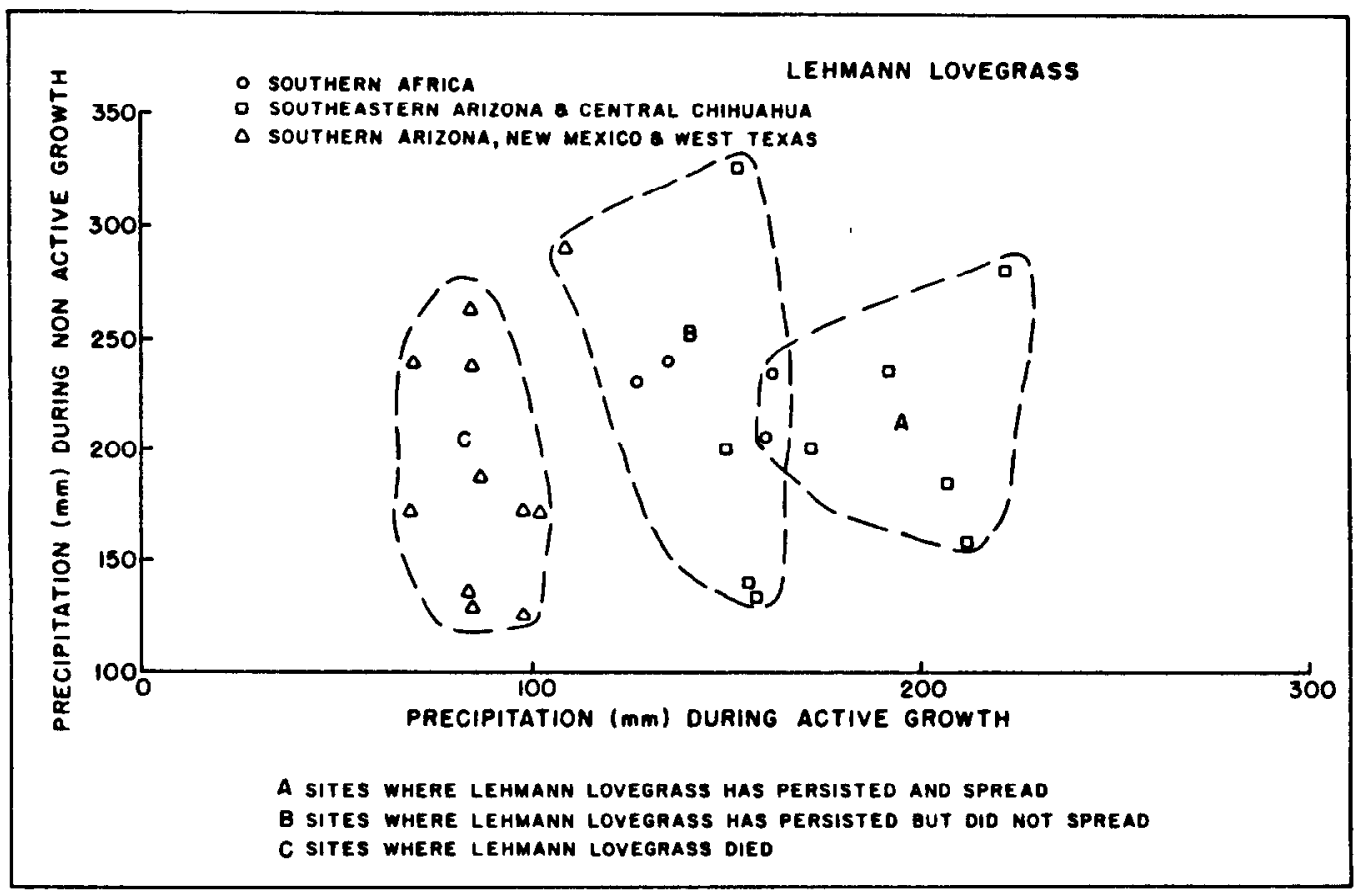

Fig. 12. The effect of winter and summer precipitation on the long-term persistence of Lehmann lovegrass in the northern and southern hemispheres.

Lehmann lovegrass normally remains semidormant. As rainfall amount and distribution increase in late summer, Lehmann lovegrass initiates growth and productivity peaks in $\mathbf{3 0}$ to $\mathbf{4 0}$ days (Fourie and Roberts 1976). Precipitation during active growth ranges from 130 to $160 \mathrm{~mm}$ (Fig. 11) while mean minimum and maximum temperatures vary from 15 to $32^{\circ} \mathrm{C}$.

Where Lehmann lovegrass has been successfully established and has spread in the southwestern United States and northern Mexico, elevations range between 775 and $1,540 \mathrm{~m}$, and daily mean minimum and maximum temperatures vary annually from -4 to $20^{\circ} \mathrm{C}$ and 13 to $38^{\circ} \mathrm{C}$, respectively (Fig. 10). Annual rainfall varies from 275 to $500 \mathrm{~mm}$, and may be distributed in a summer peak or bimodally in summer and winter (Fig. 11).

Lehmann lovegrass seed, from plants established on planted 


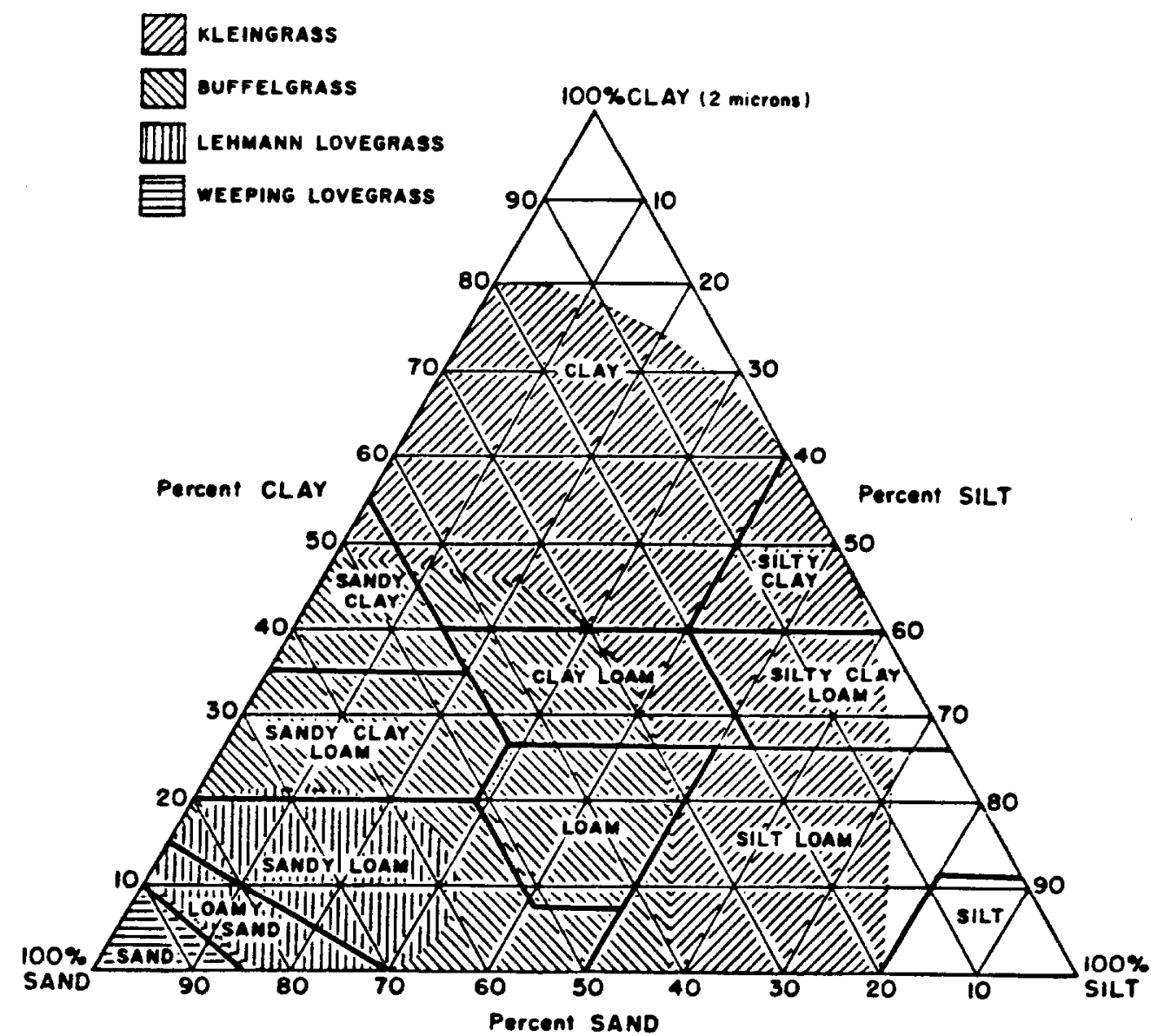

Fit. 13. The effect of soil texture on the long-term persistence of four warm-season African grasses.

sites, actively colonize adjacent nonplanted sites in southeastern Arizona (Cox and Ruyle 1986) and northcentral Mexico. At all locations, summer rainfall during active plant growth ranges from 150 to $220 \mathrm{~mm}$ (Fig. 12), and elevations vary from 1,100 to $1,540 \mathrm{~m}$ (Anderson et al. 1957, Cable 1971). Where Lehmann lovegrass has persisted but has not spread in southeastern Arizona, southern New Mexico, west Texas, and northern Mexico, summer rainfall during active growth is about $100 \mathrm{~mm}$. Established Lehmann lovegrass stands in the area die when summer rainfall during active growth ranges between 70 and $85 \mathrm{~mm}$.

\section{Effects of Soll Texture}

Buffelgrass, kleingrass, weeping and Lehmann lovegrasses have been initially established in almost all soil textural types; but long-term persistence of each grass is dependent on specific textural types (Fig. 13). Buffelgrass and kleingrass seedlings emerge when seed are sown in sandy, silty, and clayey soils, but buffelgrass emergence declines as either sand, silt, or clay content approaches 100\% (Mutz and Scifres 1975, Agostini et al. 1981). Buffelgrass seedlings gradually lose vigor and die when established in silt, silt loam, silty clay loam, silt clay and clay soils; whereas, kleingrass seedlings persist in the same soils (Sweeney and Hopkins 1975, Watt 1976, Christie 1978, Pitman et-al. 1981, Rodel et al. 1981, Hanselka 1985). Buffelgrass persists in well-drained loam, sandy loam, clay loam, and sandy clay loam soils, and actively spreads by seed in northwestern Australia and northwestern Mexico in sandy loam soils (Humphreys 1967, Cota and Johnson 1975).

Weeping lovegrass seedlings emerge from sand, loamy sand, sandy loam, and loam soils, but long-term persistence in southern Africa is normally, but not always, limited to deep sandy soils (Rethman and de Witt 1984). Sand depth may vary from 1 to $5 \mathrm{~m}$ (Farrington 1973, Wang et al. 1975, Kruger and Grunow 1983), and the soil profile may be saturated seasonally (Covas and Cairnie 1985).

In the eastern and southern United States weeping lovegrass can be established and will persist in sandy soil (Dalrymple 1976, Haferkamp and Mutz 1982). Plant distribution in this area, however, is limited by soil texture which is predominantly silt loam, clay, and clay loam. Chemical and physical characteristics of these soil types either reduce or inhibit weeping lovegrass germination (Stubbendieck 1974), seedling emergence (Cox et al. 1986), shoot growth (Chichester 1981, Lavin et al. 1981), and root growth (Tischler and Voigt 1983).

Lehmann lovegrass seedlings emerge when seeds are planted near the surface in sand, loamy sand, and sandy loam soils; seedlings, however, do not emerge in silt loam, loam, and clay loam soils, regardless of planting depth (Cox et al. 1983b). In southeastern Arizona and northcentral Mexico long-term persistence and spread is limited to loamy sand and sandy loam soils (Cox and Ruyle 1986).

\section{Discusaion}

Attempts to artificially revegetate degraded rangelands in the northern and southern hemispheres have been going on for approximately 100 years (Humphreys 1967, Cox et al. 1986). The method most widely used to establish grasses was to: (1) mechanically reduce unwanted competition, (2) prepare a seedbed, (3) plant seeds of as many species, accessions, and cultivars in as many soil types as possible, and (4) pray for rain. In 1 of every 10 planting attempts grasses were successfully established, but climatic and edaphic data were not collected and it was impossible to determine why plantings were either successes or failures.

When grasses were successfully established there was a tendency to extrapolate, because successes occurred infrequently, and imply 
that a species was adapted over a broad geographic region. Lehmann lovegrass can be established on most soils in the southwestern United States and northern Mexico in an atypically wet summer (Cox et al. 1984), but the species persists and spreads only on sandy or sandy loam soils where summer precipitation in $\mathbf{3 0}$ to 40 days varies from 150 to $220 \mathrm{~mm}$ (Cox and Ruyle 1986). Hence, Lehmann lovegrass is adapted at a few localized areas, rather than throughout the southwestern United States and northern Mexico.

The identification of climatic and edaphic factors which influence the persistence (Fig. 1-13) of the 4 African grasses can be used to predict where each grass is adapted. For example, the distribution of buffelgrass, kleingrass, and weeping lovegrass is limited when mean minimum temperatures in the coldest month are $5^{\circ} \mathrm{C}$ or less, or $0^{\circ} \mathrm{C}$ or less and $-5^{\circ} \mathrm{C}$ or less, respectively, whereas, the distribution of Lehmann lovegrass appears to be limited by the amount and distribution of summer rainfall and soil texture rather than cold temperatures. Buffelgrass requires approximately 90 growth days in summer and relatively warm, dry winters to colonize loam soils, while Lehmann lovegrass requires 30 to $\mathbf{4 0}$ growth days in summer to colonize sandy loam soils. Kleingrass and weeping lovegrass can be established and mature plants will persist where the summer growing season varies from 120 to 150 days, but neither actively invades nonplanted sites except in Africa where the growing season approaches 180 days.

Prior to 1975 it was economically feasible to seed degraded rangeland because petroleum was inexpensive. After 1975 the cost of petroleum dramatically increased and a successful seeding in 1 of every 10 attempts was no longer a worthwhile investment. If mechanical treatment and seeding is to remain a range improvement practice the probability of success must be improved. Thus, information which defines the relationships among climate and soils, and plant germination, emergence, persistence and reproduction is essential. A successful range seeding cannot be guaranteed if climate and soil are considered when selecting grasses for revegetation, but it will reduce the probability of failure.

\section{Literature Cited}

Alberto, G., and I.L. Barreto. 1983. Comparisons between cultivars of Panicum maximum and Panicum coloratum under the effects of legumes and rates of nitrogen. (In Portuguese). Revista da Sociedade Brajileira de Zootecnia 12:440-457.

Anderson, D., L.P. Hamilton, H.G. Reynolds, and R.R. Humphrey. 1957. Reseeding desert grasslands in southern Arizona. Arizona Agr. Exp. Sta. Bull. 249. Tucson.

A goatini, J.J., J.A. Morales, and D. Emkerlins. 1981. Yield and quality of two hybrids of buffelgrass (Cenchrus ciliaris) damaged by different populations of the spittlebug (Aneolamia albofasciata) and mites (Prosapia simulans). (In Spanish). Agronomia 200:42-47.

Axmi, M.I., and A. Singh. 19s5. Pathogenicity of Tylenchorhynchus vulgaris on Anjan grass, Cenchrus ciliaris cv. Igfri-S-3108. Indian J. Nematology 14:184-185.

Bade, D.H., B.E. Conrad, and E.C. Hoit. 1985. Temperature and water stress effects on growth of tropical grasses. J. Range Manage. 38:321-324.

Bedunah, D.J., and R.E. Sosebee. 1985. Influence of site manipulation on infiltration rates of depleted west Texas range sites. J. Range Manage. 38:200-205.

Bogdan, A.V. 1961. Breeding behavior of Cenchrus ciliaris in Kenya. East Afr. Agr. and Forest. J. 26:241.

Bridges, J.0. 1941. Reseeding trials on arid range. New Mexico Agr. Exp. Sta. Bull 278. Las Cruces.

Brooks, G.B. 1929. Queensland Department of Agriculture and Stock Annu. Rep., 1928-1929. Brisbane, Australia.

Cable, D.R. 1971. Lehmann lovegrass in the Santa Rita Experimental Range, 1937-1968. J. Range Manage. 24:17-21.

Chichester, F.W. 1981. Preliminary evaluation of forage grass growth on mine spoil materials from an east central Texas site. I. Overburden strata. Soil Sci. 132:204-212.

Chritle, E.K. 1978. Ecosystem processes in semiarid grasslands. I. Primary production and water use of two communities processing different photosynthetic pathways. Aust. J. Agr. Res. 29:773-787.

Cooke, R.U., and R.W. Reeves. 1976. Arroyos and environmental change in the American Southwest. Oxford Press, London.
Cotn, A., and D. Johneon. 1975. Adaptation and production of ten perennial grass species in Sonora. (In Spanish). Pastizales-CI-MP-00I. Hermosillo, Mexico.

Covas, G., and A.G. Calmie. 1985. Weeping lovegrass; A basic information manuel for its establishment and utilization under normal conditions. (In Spanish). Editorial Hemisferio Sur S.A., Buenos Aires.

Cox, J.R., H.L. Morton, J.T. Labaume, and K.G. Renard. 1983a. Reviving Arizona's rangelands. J. Soil and Water Conserv. (USA) 38:342-345.

Cox, J.R., H.A. Schrelber, and H.L. Morton. 1983b. The initial growth of two range grasses collected on nonfertilized and fertilized soils collected from creosotebush communities in the southwestern United States. J. Range Manage. 36:726-729.

Cox, J.R., J.M. Parker, and J.L. Stroehlein. 19:4. Soil properties in creosotebush communities and their relative effects on the growth of seeded range grasses. Soil Sci. Soc. Amer. J. 48:1442-1445.

Cox, J.R., M.H. Martin-R., F.A. Ibarm-F., and H.L. Morton. 1986. Establishment of range grasses on various seedbeds at creosotebush (Larrea tridentata) sites in Arizona USA, and Chihuahua, Mexico. J. Range Manage. 39:540-546.

Cox, J.R., and G.B. Ruyle. 1986. Influence of climatic and edaphic factors on the distribution of Eragrostis lehmanniana Nees in Arizona. J. Grassl. Soc. Sth. Afr. 3:25-29.

Cresswell, C.F. 1973. Changes in vegetational composition, nutritional status, soils, and microbial populations with the establishment of vegetation on gold-mined dumps on the Witwatersrand. p. 335-359. In: R.J. Hutnik and $G$. Davis (ed.). Ecology and reclamation of devastated land. Gordon and Breach Co., New York.

Crider, F.J. 1945. Three introduced lovegrasses for soil conservation. USDA Circular 730. U.S. Government Printing Office, Washington, D.C.

Dalrymple, R.L. 1976. Bermudagrass and weeping lovegrass mixtures for forage. The Samuel Roberts Noble Foundation, Agr. Div. No. BWL-76. Admore, Okla.

Dalrymple, R.L, and J.L. Rogers. 1983. Allelopthic effects of western ragweed on seed germination and seedling growth of selected plants. J. Chem. Ecology 9:1073-1078.

Das, R.B., G.N. Bhat, and V.D. Joahi. 1978. Plant growth rhythm and protein status of desert forage grasses: Cenchrus ciliaris and Panicum antidotale. Forage Res. 4:97-99.

Denman, C.E., W.C. Elder, and V.G. Heller. 1953. Performance of weeping lovegrass under different management practices. Oklahoma Agr. Exp. Sta. Tech. Bull. No. T-48. Stillwater.

Dollhhte, J.W., R.L. Younger, and L.P. Jones. 1977. Photosensitization in lambs grazing kleingrass (Panicum coloratum). J. Amer. Vet. Med. Ass. $171: 1264-1265$.

du Tolt, J., J.W. Rable, and J.O. Grunow. 1973. Nutritional production studies on Cenchrus ciliaris L. c.v. Molopo. Proc. Grassl. Soc. Sth. Afr. (In Afrikaans). 8:107-115.

Dye, P.J., and B.H. Walker. 19e0. Vegetation-environment relations on sodoc soils of Zimbabwe Rhodesia. J. Ecology 68:589-606.

Dwyer, D.D., P.L. Sims, and L.S. Pope. 1974. Preference of steers for certain native and introduced forage plants. J. Range Manage. 17:83-85.

Ehara, S. 1985. Five species of phytoseiid mites from Japan with descriptions of two new species (Acarina, Phytoseiidae). Zoological Sci. 2:115-121.

Farrington, P. 1973. The seasonal growth of lovegrass (Eragrostis curvula) on deep sandy soils in a semiarid environment. Aust. J. Exp. Agr. and Anim. Husb. 13:383-388.

Fourte, J.H., and B.R. Roberts. 1976. A comparative study of three veld types of the Northern Cape: Species evaluation and yield. Proc. Grassl. Soc. Sth. Afr. 11:79-85.

Gallardo, A., and A. Leone. 1983. Pasture evaluation in the desert zone of Venezuela for the development of goat production. p. 367-369. In: J.A. Smith and V.W. Smith (ed.). Proc. XIV Int. Grassl. Congress, Lexington, Kentucky. Westview Press, Boulder, Colo.

Giraudo, C.G., C.A. Fradinelli, E. Verzes, and A. Marchi. 1984. Effect of paraquat on quality of deferred weeping lovegrass. (In Spanish). Revista Argentina de Produccion Animal 4:43-49.

Gnanapragasam, N.C. 1981. The influence of cultivation on Eragrostis curvula in nematode-infested soils, on the subsequent build-up of populations in replanted tea. Tea Quarterly 50:160-162.

Grifith, D. 1901. Range improvement in Arizona. USDA, Bureau of Plant Industry, Bull. 67. U.S. Government Printing Office, Washington, D.C. Haferkamp, M.R., and J.L. Mutz. 1982. Evaluation of grasses for selected sites in the south Texas plains. Texas Agr. Exp. Sta. MP-1507. College Station. 
Hanselka, C.W. 1985. Grazing management strategies for buffelgrass. p. 53-64. In: E.C.A. Runge and J.L. Schuster (ed.). Buffelgrass: Adaptation, management and forage quality Symposium. Texas Agr. Exp. Sta. MP-1575. College Station.

Harh, L.N., C.M. Verma, and B.L. Jain. 1981. Relationship between precipitation and forage production of Cenchrus ciliaris in arid regions. Annals Arid Zone 20:101-106.

Hoh, E.C. 1969. Kleingrass 75. Texas Agr. Exp. Sta. TAP-518. College Station.

Holt, E.C. 1985. Buffelgrass-A brief history. p. 1-5. In: E.C.A. Runge and J.L. Schuster (od.). Buffelgrass: Adaptation, management and forage symposium. Texas Agr. Exp. Sta. MP-1575. College Station.

Holt, E.C., M.A. Huasey, J.C. Read, and R.M. Jones. 1985. Kleingrass cultivar evaluations. Texas Agr. Exp. Sta. PR-4263. College Station.

Humphreys. L.R. 1967. Buffelgrass (Cenchrus ciliaris) in Australia. Trop. Grassl. 1:123-134.

Huasey, M.A., and E.C. Holt. 1982. Selection and evaluation of heavy seed/ weight synthetic cultivars of kleingrass. Texas Agr. Exp. Sta. Cpr4024. College Station.

Hondan, F., and I. Dahi. 1982. Some preliminary studies on the interference exhibited by Bothriochloa pertusa (L.) A Camus. Pakistan J. Botany $14: 16$

Inoarlo, M., K. Ito, H. Numaguchi, M. Aratani, and K. Maeda. 1975. Studies on the productivity of some tropical grasses. I. Relationship between heading rate and dry matter yield under different cutting treatments. (In Japanese). Japanese J. Trop. Agr. 18:87-92.

Ivory, D.A., T.H. Stobbe, M.N. McLeod, and P.E. Whiteman. 1974. Effect of day and night temperatures on estimated dry matter digestibility of Cenchrus ciliaris and Pennisetum clandestinum. J. Aust. Inst. Agr. 40:156-158.

Ivory, D.A., and P.C. Whiteman. 1978. Effect of temperature on growth of five subtropical grasses. I. Effect of day and night temperature on growth and morphological development. Aust. J. Plant Physiol. 5:149-157.

Judd, I.B., and L.W. Judd. 1976. Plant survival in the arid southwest 30 years after seeding. J. Range Manage. 29:248-251.

Kategile, J.A. 1985. Pasture improvement research in eastern and southern Africa. Int. Development Res. Center, Ottawa, Canada.

Khan, S.M., and R.M. Zarif. 1942. Enhancing range productivity through grass seeding in subtropical semiarid shrublands near Peshawar. Pakis$\tan$ J. Forest. 32:89-94.

Kobayashi, T., S. Nithimum, and S. Tanaka. 1978. Growth of tropical and subtropical grasses in the southwestern area of Japan as influenced by air temperature. I. Effects of sowing date, growth stage and cutting frequency on growth and yield. (In Japanese). Sci. Bull. Faculty of Agr. Kyushu Univ. 32:169-175 (Fukuoka)

Kruger, A.J., and J.O. Grunow. 1983. Dry matter production and quality characteristics of 40 Eragrostis curvula ecotypes. (In Afrikaans). Agroplantae 15:45-52.

Lavin, F., T.N. Johneen, JR. and F.B. Gomm. 1981. Mulching, furrowing and fallowing of forage plantings on Arizona pinyon-juniper ranges. $J$. Range Manage. 34:171-177.

Lloyd, D.L., J.G. Natton, T.B. Hilder, and P.X. ORourke. 19a3. Productivity of grazed Makarikari grass-lucerne, Rhodesgrass-lucerne and lucerne pastures in the northern wheat belt of Australia. Aust. J. Exp. Agr. and Animal Husb. 23:383-392.

Mackende, J., R. Mayer, and W.J. Dianet. 1922. Productivity of five subtropic grasses on a black earth of the eastern Darling Downs of Queensland. Trop. Grassl. 16:170-180.

Milli, P.F.L. 1977. Comparisons of the yield and palatability of Digitaria, Cynodon, Eragrostis, Panicum and Brachiaria species and cultivars when defoliated at different frequencies and heights at two sites. Rhodesia (Zimbabwe) Agr. J. 74:159-163.

Molina, S.I., T.R. Garza, and H.M. Torres. 1976. Beef production on guinea and buffelgrasses with two fertilizer rates, during one year in Tizimin, Yucatan. (In Spanish). Tecnica Pecuaria en Mexico 31:17-21.

Muchir, D.J., C.H. Bridges, D.N. Ueekert, and E.M. Balley. 19as. Photosensitization of sheep on kleingrass (Panicum coloratum) pasture. J. Amer. Vet. Med. Ass. 177:353-354.

Mukurai, N.J. 194. The response of tropical grasses to higher rates of nitrogen at Uyole, Tanzania. Lantbruksuniversitet 131:53-66.

Mulberjee, A. 1972. Effect of nitrogen on the growth of Panicum in sandy soil. Indian Agriculturist 16:199-200.

Mutz, J.L., and C.J. Seifres. 1975. Soil texture and planting depth influence buffelgrass emergence. J. Range Manage. 28:222-224.

Nada, Y. 1955. Palatability and adaptability of ten tropical grasses used as grazing pasture in Kyushu. J. Japanese Soc. Grassl. Sci. 30:434-440.
National Animal Husbandry Reaearch Station Annual Report from Naivasha, Kenya. 1979. Annual Report of the Scientific Research Division 1975. Ministry of Agr. Res. Rep. pp. 162-178.

Nieto, F.G. 1985. Eragrostis curvula; a new grass for the Spanish flora. (In Spanish). Anales del Jardin Botanica de Madrid. 42:255

Novoand, A.C., D.J. Dornett, G.W. Sultemeler, F.C. Petr, and J.N. Pratt. 1983. Weeping lovegrass. Texas Agr. Ext. Serv. Leaflet 1207. College Station.

Oquendo, G., J. Gerardo, and E. Mantecon. 1983. Performance of pasture cultivars on brown soils in Guaimaro. (In Spanish). Pastos and Forrajes 6:319-329.

Pitman, W.D., D.M. Vletor, and E.C. Holt. 1981. Digestibility of kleingrass forage grown under moisture stress. Crop Sci. 21:951-953.

Pitman, W.D., and E.C. Hoh. 1983. Herbage production and quality of grasses with livestock and wildlife values in Texas. J. Range Manage. 36:52-54.

Pratt, J.M., A.C. Novoesad, K.E. Lndey, D.A. Lovelace, R.B. Metzer, and F.C. Petr. 1971. Keys to profitable permanent pasture production in west Texas. Texas Agr. Ext. Serv. MP-981. College Station.

Read, J.C., B.J. Simpen, and LJ. Streetman. 19s0. Registration of Renner weeping lovegrass. Crop Sci. 20:670.

Reen, M.C. 1972. Winter and summer growth of pasture species in a high rainfall area of southeastern Queensland. Trop. Grassl. 6:45-54.

Reih, P.R., W. Botelho, L.A.S. Melo, and J. Kalida. 194. Pasture froghoppers (Sulia entreriana) in the north of Minas Geruis State, Brazil. (In Portuguese). Anais de Sociedada Entomologica de Brazil 13:225-236.

Rethman, N.F.G., and C.C. de Witt. 19s4. The production potential of pure and mixed stands of Eragrostis curvuala and Medicago sative on the eastern Transvaal highland. J. Grassl. Soc. Sth. Afr. 1:30-32.

Rodel, M.G.W. 1972. Effects of different grasses on the incidence of neonatal goitre and skeletal deformities in autumn born lambs. Rhodesia (Zimbabwe) Agr. J. 69:59-60.

Rodel, M.G.W, J.A. Shepherd, and G. Seheerhoom. 1976. Effects of plant parasitic nematodes on growth of grasses. p. 114-115. In: Annual Report, Henderson Res. Sta., Salisbury, Rhodesia (currently Harrie, Zimbabwe).

Rodel, M.G.W., J.N. Boultwood, and L. MeNelll. 19s1. The response of four grasses to applied nitrogen in two soils. Zimbabwe J. Agr. Res. 19:7-49.

Rodel, M.G.W., and J.N. Boultwood. 19a1. Effects of defoliation frequency on yield and composition of shoots and roots of three grasses of different growth habits. Zimbabwe J. Agr. Res. 19:151-162.

Rommann, L.M., and W.E. MeMurphy. 1974. Weeping lovegrass. Oklahoma State Univ. Ext. Facts No. 2556. Stillwater.

Sanchez, A. 1976. The production of Lehmann lovegrass in Chihuahua. (In Spanish). Pastizales 7:2-8. Chihuahua, Mexico.

Sellers, W.D., and R.D. Hill. 1974. Arizona climate. Univ. of Arizona Press, Tucson.

Shoop, M.C., and E.H. Mellvin. 1970. Winter grazing of weeping lovegras in northern Oklahoma. p. 122-129. In: R.L. Dalrymple (ed.). Proc. Weeping lovegrass symposium. Samuel Roberts Noble Foundation, Ardmore, Okla.

Shoop, M., E.H. Mellvain, and P.W. Voitt. 1976. Morpa weeping lovegrass produces more beef. J. Range Manage. 29:101-103.

Stubhendieck, J., P.T. Koohi, and W.G. MeCully. 1973. Establishment and growth of selected grasses. J. Range Manage. 26:39-41.

Stubbendieck, J. 1974. Effect of pH on germination of three grass species. J. Range Manage. 27:78-79.

Sweeney, F.C., and J.M. Hoptineon. 1975. Vegetative growth of nineteen tropical and semi-tropical pasture grasses and legumes in relation to temperature. Trop. Grassl. 9:209-217.

Tallaferro, C.M., R.M. Alring, and W.L. RJehardeon. 1933. Registration of OKPC-1 Kleingrass germplasm. Crop Sci. 23:190.

Thormber, J.J. 19e5. Range improvement. Arizona Agr. Exp. Sta. 16:1722. Tucson.

Thehler, C.H., and P.W. Voift. 19a3. Effect of planting depth on vegetative characteristics of three forage grasses at 14 days post emergence. Crop Sci. 23:481-484.

van den Berg, E. 1935. Notes on the genus Afrina brzeski, 1981 (Anguinidae:Nematoda) with descriptions of new and known species. PhytophyInctica 17:67-79.

van der Merwe, W.J.J., A. Bicker, W.F.O. Marosas, and T.S. Kelleranan. 1979. Aerospora of an Eragrostis curvula pasture in South Africa. (In Afrikans). Onderstepoort J. Vet. Res. 46:19-25.

Vointh, F.W. 1971. Registration of Morpa weeping lovegrass. Crop Sci. 11:312-313. 
Volt, P.W., C.L. DeWald, J.E. Matochn, and C.D. Foy. 1982. Adaptation of iron-efficient and inefficient lovegrass strains to calcareous soils. Crop Sci. 22:672-676.

Wang, H.T., S.M. Chang, C.W. Chent, and C.S. Chang. 1975. Observations on cover crops and mulching on a steeply sloping orchard. J. Agr. Ass. China. 1:69-76.

Watt, L.A. 1976. Evaluation of pasture species for soil conservation on cracking black clays-Gwydir district, northwestern New South Wales. J. Soil and Water Cons. (New South Wales) 32:86-97.
Watt, I.A. 19a3. Improving grass seedling establishment on black earths. J. Soil and Water Cons. (New South Wales) 39:201-207.

Winkworth, R.E. 1963. The germination of buffelgrass (Cenchrus ciliaris) seed after burial in a Central Australian soil. Aust. J. Exp. Agr. and Anim. Husb. 3:326. 